\title{
Environmental Influences on the Settlements Patterns of Communities in the Marshes of Iraq
}

\author{
Suhail Najim ${ }^{*}$, Nadia A. Alslam², Inaam A. Albazzaz ${ }^{3}$ \\ ${ }^{1}$ Architectural Engineering Department, Engineering College, University of Samarra, Samarra 34010, Iraq \\ ${ }^{2}$ Centre of Urban and Regional Planning for Post Graduate Studies, University of Baghdad, Baghdad 10001, Iraq \\ ${ }^{3}$ Department of Architectural, Engineering College, University of Baghdad, Baghdad 10001, Iraq
}

Corresponding Author Email: suhail.najim@uosamarra.edu.iq

\section{https://doi.org/10.18280/ijdne.160606}

Received: 14 September 2021

Accepted: 19 November 2021

\section{Keywords:}

Mesopotamia, marshes, Aljabayesh, cultural heritage, rural settlement economy, environmental adaptation, construction techniques, growth pattern

\begin{abstract}
In the field of residential community planning, one of the appropriate places to study the mutual influences between man and the environment, away from the influences, concepts and mechanisms of contemporary planning theories are isolated environments in rural areas, and the marshlands in Iraq represent one of these models. These areas still retain the planning patterns of residential communities for thousands of years. This research attempts to conduct a descriptive study of traditional settlement patterns, which relied on the capabilities of the surrounding areas to provide planning and architectural solutions based on the environmental factor. Establishing such a clear framework for these impacts can help in any future interventions or development processes in the region and ensure that any random or irregular interventions that may have occurred previously are not repeated. Which will preserve the components and sustainability of this ecosystem and maintain the harmony and integration between the elements of the architectural environment and the natural elements.
\end{abstract}

\section{INTRODUCTION}

The marshes of Iraq were once a refuge for biological diversity and the mother home of the ancient cities of Mesopotamia [1]. It is the land of the Garden of Eden and it contributed to the formation of the mythical image of the eternal conflict between man and nature in one of the most famous historical epics "The Epic of Gilgamesh"[2]. These marshes were one of the largest wetland areas in the world and the most culturally rich (Figure 1).

The climate humidity and the high level of the sea waters in the Gulf for most of the 5th millennium BC caused the formation of a swampy environment in the silt areas in the south, and the high lands turned into islands and platforms on which the first settlements in the region were built. After that, in the 4th millennium BC, the weather became colder and more arid, and the Euphrates-Tigris delta extended again towards the south [3]. This led to the formation of different settlement patterns [4]. Like many other regions of the world, these early settlements were established initially as summer camps or for fishing [5]. Then it gradually turns into permanent settlements and cities [3].

Natural materials, especially reeds, have been used for centuries in the construction of these settlements, in a way that is still used to this day, except for the use of electricity for lighting and ventilation and some new patterns for door and window openings that reflect the tastes of their users. Nothing has changed (Figure 2). These dwellings are almost identical to those built during the Sumerian era, giving the buildings and the region a timeless architectural form characterized by lightness and beauty and perfectly adapted to the climatic conditions of the marshes [6].

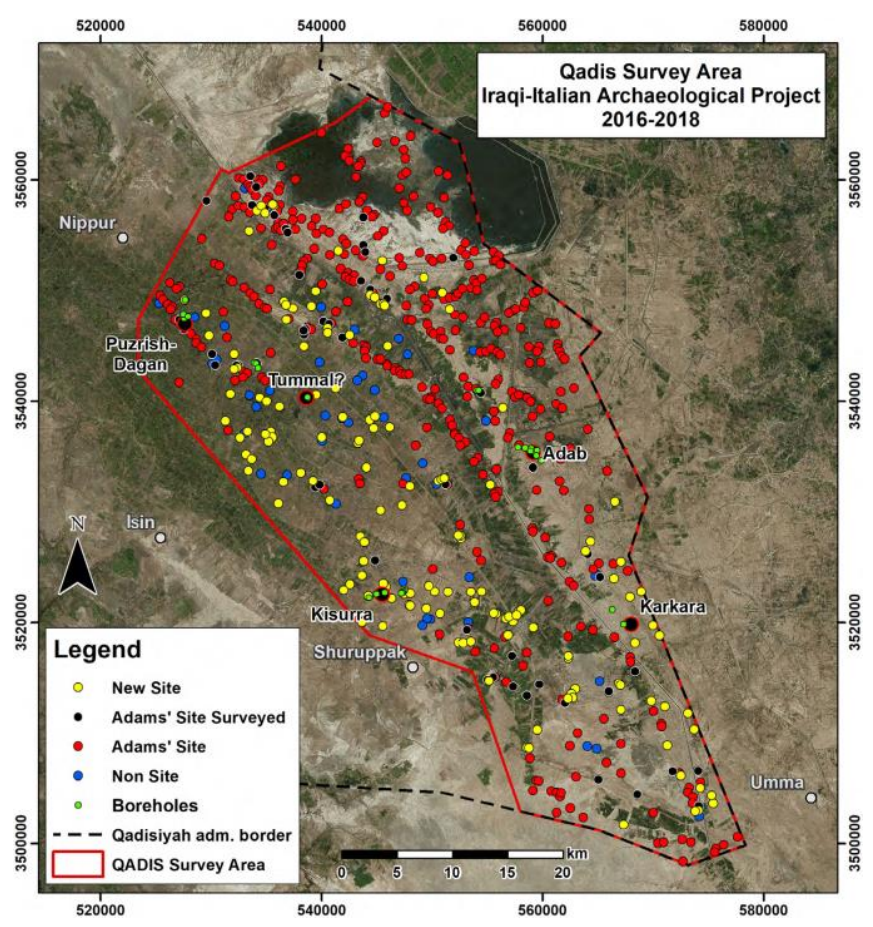

Figure 1. Distribution of archaeological sites in the central marshlands [3]

Soon, the ancient cities of Nippur, Ur, Shuruppak, Isin, Lagash, and many others developed on the banks of these marshes $[7,8]$, and these areas remained inhabited for nearly 6000 years, but wars, desiccation, and establishing a huge hydraulic facility on the course of the Tigris and Euphrates 
rivers in Turkey, Syria, and Iran, in addition to the problems of global climate-changing and increasing water demand [9]. All this led to the migration of its population to the cities and the decay of many methods in construction and planning.

In addition to its cultural and population richness, this region is characterized by possessing a large number of natural economic capabilities and a variety of environmental resources in addition to their environmental diversity such as fish, birds, and natural building materials [10].
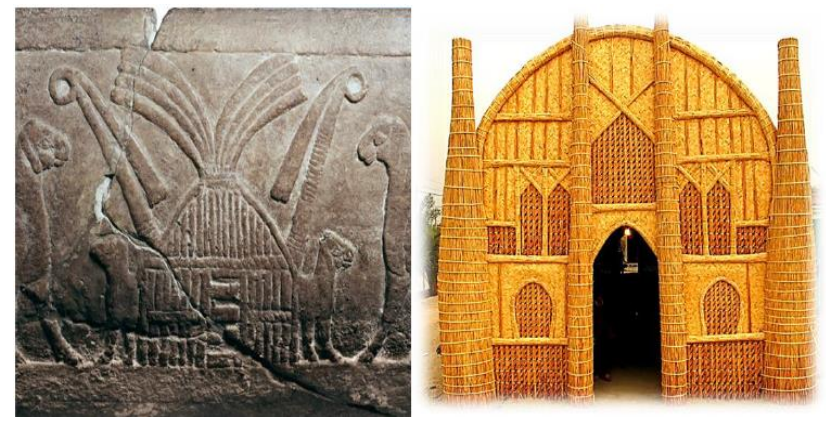

Figure 2. Similarities between present reed houses and ancient mud tablet reed houses [11]

\section{MUTUAL INFLUENCE BETWEEN MAN AND ENVIRONMENT IN IRAQ MARSHLANDS}

The diverse interaction between the marshes residents and this sensitive, highly productive ecosystem, produced cultural aspects closely related to what this environment offers them and contributed to the formation of a set of values and rules that they used in shaping the context of the architectural environment in the marshes [6].

Architecture does not only create a place to live, but it creates the values that individuals use to express themselves and define their culture, and thus it is an important and political act that affects the experiences of the people involved in it physically, spiritually, and emotionally [12].

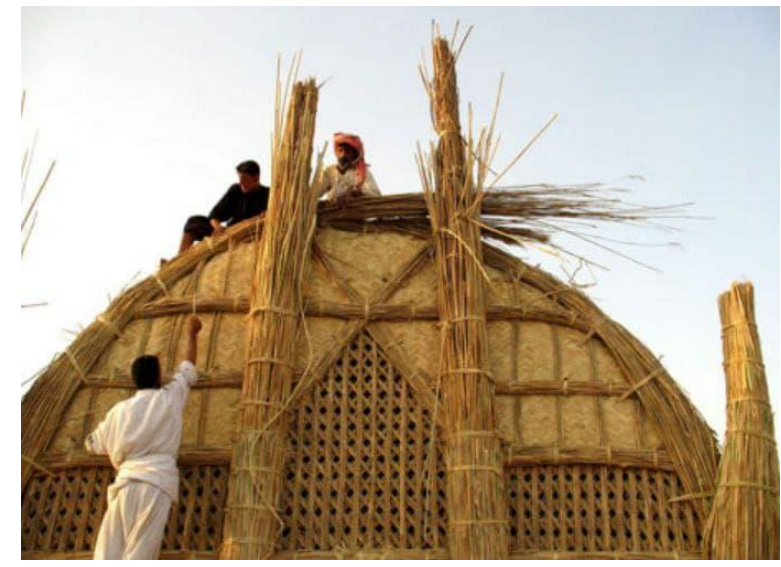

Figure 3. Teamwork houses construction [13]

This can be seen in the social customs and behaviors that link the population to their environment and in the collective participation in the construction of homes (Figure 3), grazing, agriculture, and fishing. The rural and agricultural nature of the marshes doubled the need for cheap labor, which pushes the families to have more children, and this is what generated large families. When children grow up, and separate from their original family, they remain economically linked to it, so they build their homes near their parents' homes, this was the reason for the formation of socially and economically linked settlements [14].

Good rainy years (2004-2008) restored 58\% of the original marsh area, but this process worked in some places and failed in others. The suitability of the marshes for meditation, tourism, and transportation [15] would help the region to develop and prosper and also in the return of its native inhabitants.

The building materials that are used in the architectural heritage of rural buildings are common and abundant in these areas, but at the same time, with traditional building techniques, they do not last for a long time, which requires continuous maintenance and replacement [16], even the islands on which dwellings are built, are also subject to erosion and drowning due to climate and floods, but artificial floating platforms can be used as an alternative to islands and service buildings required by the marshes [17].

Also, traditional building materials such as reeds and mud can be mixed with cement mortar, that will improve the environmental and structural properties of both [18], and contributes to extending the life span of buildings.

In order to have a clearer understanding of the nature of the human-environment relationship in the marshes, it is necessary to understand the factors that contributed to the formation of settlement patterns, and thus it will be possible to restore this environment without causing damage or any negative change there.

\section{CONTEXT-BASED SETTLEMENTS PLANNING PATTERNS IN IRAQ MARSHLANDS}

Although the marshland is a homogeneous tissue due to the presence of vast water areas and reed plants, it is possible to find a sub-divided context within this tissue depending on the type of natural resources present in each context, the following types of settlements can be distinguished.

\subsection{Open marshland context}

They formed the most significant part of the Marshland settlements and were located in the central part of it, in addition to the areas where predominantly water bodies and reed forests. Settlements appear in the form of floating islands in the middle of reeds where water is the only means of transport [19]. These villages appear radial or centrally planned where the village and its services gather in a central area of open water and extend on the banks of waterways that penetrate the reeds fields (Figure 4).

There are also settlements in this environment with a longitudinal pattern and although they provide a central axis that can contain the public services of the village, the main problem here is pollution. The polluted water is collected from the houses at the top of the village and transported with water to the houses below, rising the degree of pollution to the maximum. Another pattern can be noticed in some large settlements, where the village is divided into two or more smaller segments (Figure 5). For example, they meet around a major waterway that provides access to the different services of the village such as school, health center, and other administrative services, and these two sections are divided into a large group of islands (macro islands) and then to a smaller 
group (micro islands) which are a separate housing unit for families. This pattern was developed based on the practical experiences of the residents over a long period of time. Where, the general outline of the island units takes a longitudinal trend facing the current, while the essential spaces-oriented southwest towards Mecca. Thus, the main direction of the islands is mainly defined by these two directions (water stream, prayer direction). This internal organization of the settlement differs from the external organization of the villages, as the external form results from the need to create waterways that represent the shortest roads from the village towards the reed fields and neighboring villages.

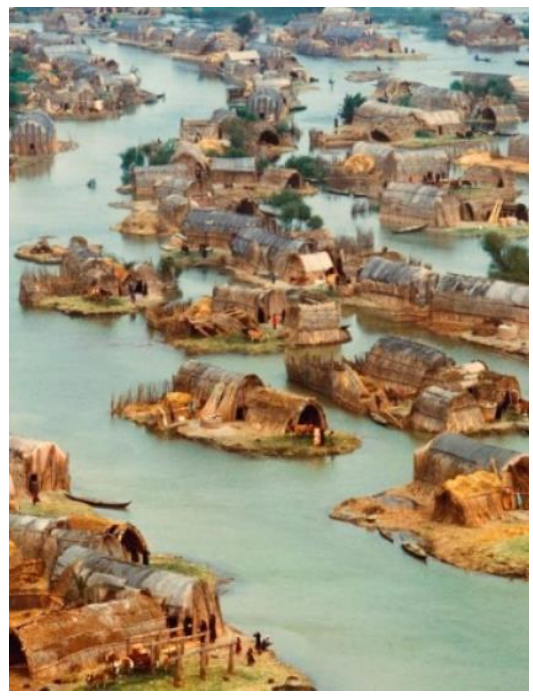

Figure 4. Open marshland context [13]

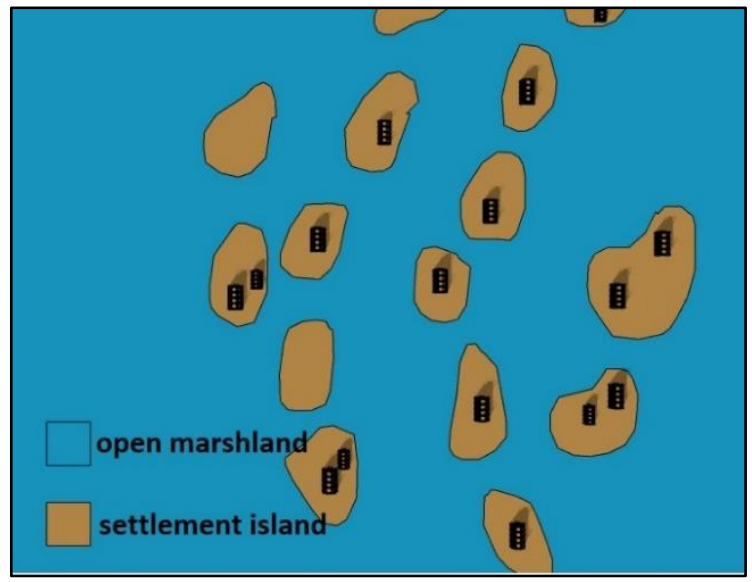

Figure 5. Open marshland pattern settlement

\subsection{Palm Forest context}

It includes the areas extending both sides of the Euphrates River. Where the presence of palms in the area gives the environment a unique view along the Riversides, where it is parallel to it and extends towards the north. Construction techniques vary in this region, depending on the existing resources, as a result of its contact with the marshes on the eastern side, the desert lands on the western side, and the south the permanent marshes. Settlements often fall in the southern part of the palm forests to get the best potential offered by the environment where: In winter, palm forests can act as windbreaks. In summer can create shadows and humid wind coming towards the settlement (Figures 6,7).

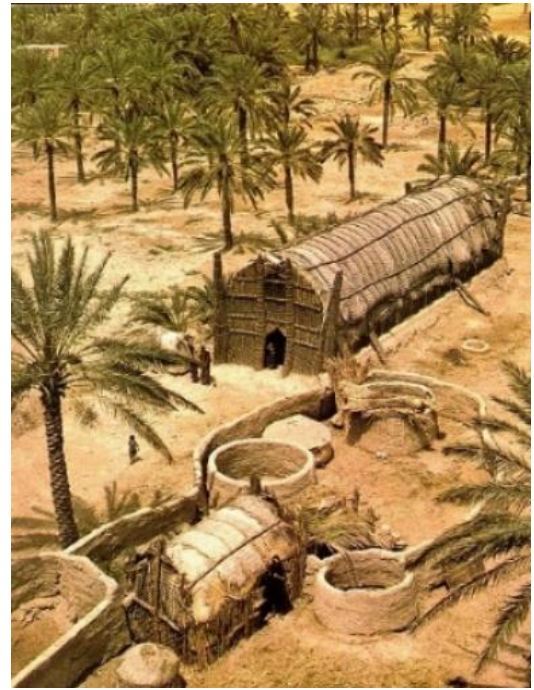

Figure 6. Palm Forest context [20]

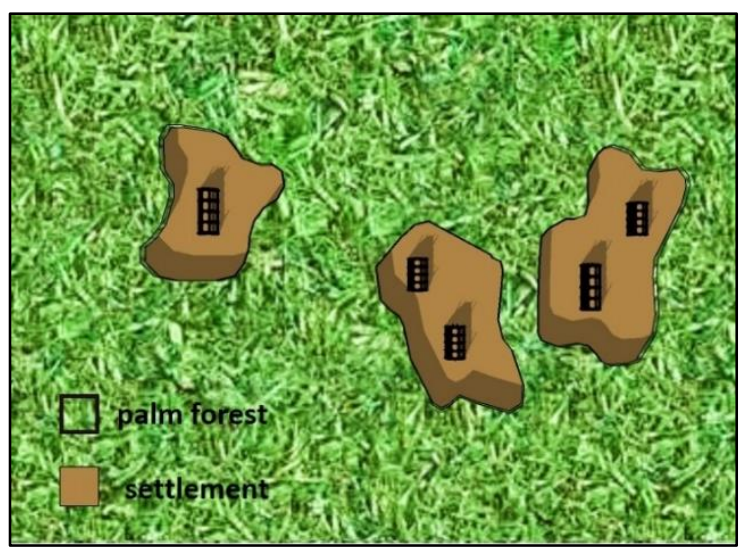

Figure 7. Palm Forest context settlement

\subsection{Irrigated areas context}

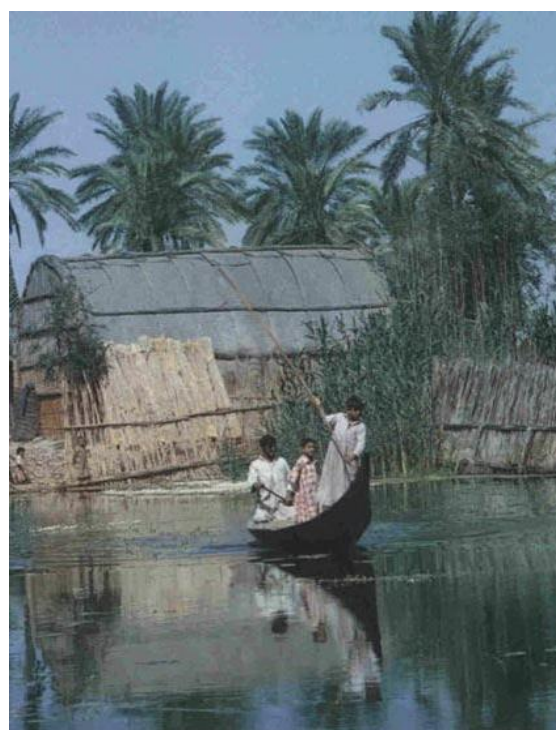

Figure 8. Irrigated areas context [21]

In this area, the context provides all the requirements for cultivating the land. The space organization of the housing units is mainly affected by the existence of water channels that constitute a vital nerve for agriculture and water supply. As a result, rational planning dominates the region because of 
irrigation canals, where agriculture is the economic basis for the environment (Figure 8, 9a-9b). The presence of canals and shows a precise balance between the settlements and the volume of resources in the irrigated fields (compared to the settlements of other marsh environments) The units are commensurate with the resources of the area and often the family ownership limits are represented by the main or secondary channel around the land they own [19].

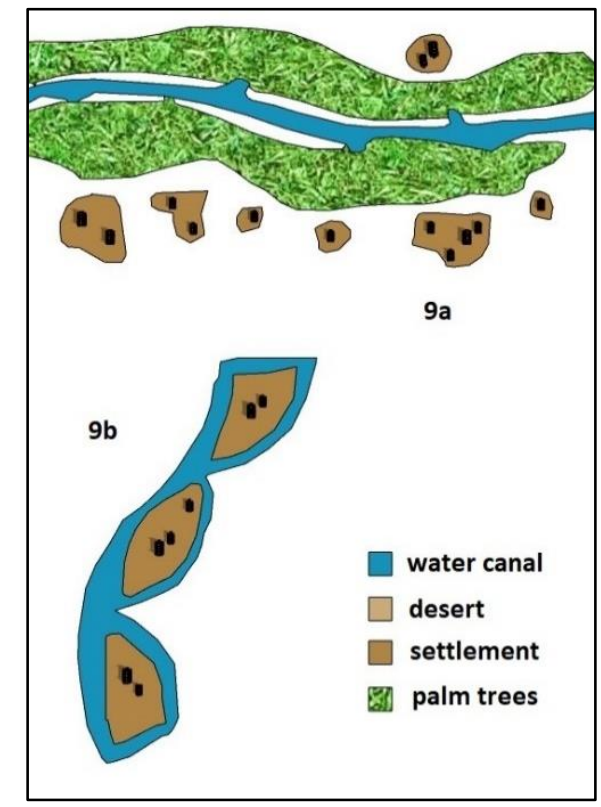

Figure 9. Irrigated areas context settlement

\subsection{Desert - Marshes areas context}

This environment comes in the second degree of breadth, settlements in this environment are irregularly distributed because they depend on the availability of grass to graze sheep and camels, this environment is the most difficult in terms of adaptation to housing because of the contrast in the environment and climate between the two seasons: the flood, where the land floods with water, sometimes as deep as $1.8 \mathrm{~m}$ and dry season when the land returns to its deserted nature [22].

The variance in the context of the marshland environment (Figure 10) and the nature of available resources affect the economic situation of the marshland inhabitants. In the open marshes, when water levels rise during the flood season, the nature of resources will mainly depend on fishing. In other seasons it turns to graze water buffalo, harvesting reeds and making its products. In palm forests, the economic resources range from the reed provided by the marshes and from palm products (dates, fronds, and trunks), the outskirt of the desert area is a suitable environment for grazing and farming. While in the desert environment, economic alternatives are limited, as they depend on the availability of herbs to graze the sheep.

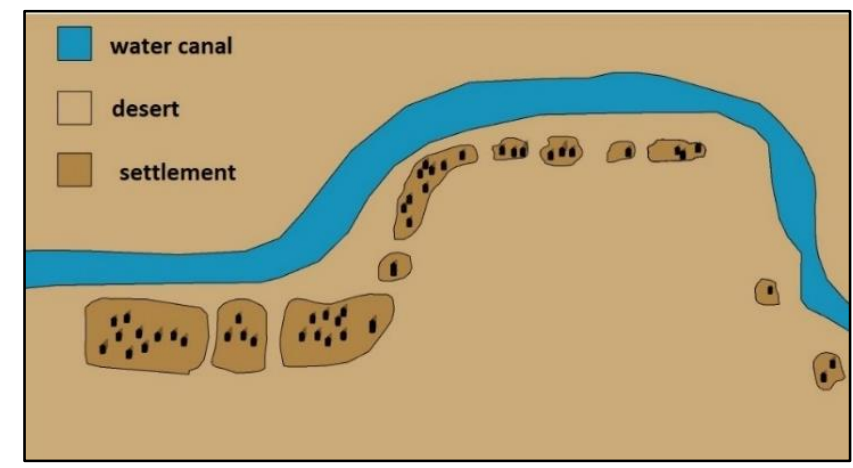

Figure 10. Desert - Marshes areas context settlement

\section{THE IMPACTING FACTORS ON SETTLEMENT PLANNING: SEE (TABLE 1)}

\subsection{Pollution and waste disposal}

The marine environment in the marshes has a dual effect on the settlements: positively through the provision of economic resources and mitigating the climate, and negatively through the spread of pollution. This is mainly affected by the density of the population.

In this lonely and isolated environment, most of the residents prefer to live near to each other for social and defensive reasons, thus, the amount of waste in and around the settlement will increase, and the quantities of water buffaloes feces that they raise will increase too. This accumulation is the main cause of pollution in the marshes. as a solution to this problem, some residents are directing the settlement is in eastwest orientation, in a direction perpendicular to the water current, which is north to south, that was helpful in the process of self-purification of the settlement and the disposal of waste [23].

Table 1. Planning factor: Properties \& nature

\begin{tabular}{|c|c|c|}
\hline $\begin{array}{l}\text { Impact Factors on } \\
\text { Settlement Planning }\end{array}$ & Related Properties & Impact Nature \\
\hline $\begin{array}{l}\text { Pollution and Waste } \\
\text { Disposal }\end{array}$ & $\begin{array}{l}\text { Population density, } \\
\text { Settlement } \\
\text { Orientation }\end{array}$ & $\begin{array}{l}\text { Pollution increases with increasing population } \\
\text { Pollution decreases when the settlement is directed with the direction of the waterflow }\end{array}$ \\
\hline $\begin{array}{l}\text { The Nature of The } \\
\text { Settlement Economy }\end{array}$ & $\begin{array}{l}\text { economic resources } \\
\text { of context type }\end{array}$ & $\begin{array}{l}\text { In open marsh villages, the settlements are spread around reed fields. } \\
\text { In palm forest villages are distributed in a striped form. } \\
\text { In desert lands no clear pattern was found. }\end{array}$ \\
\hline $\begin{array}{l}\text { The Settlement Growth } \\
\text { Pattern }\end{array}$ & nature of the context & $\begin{array}{l}\text { In open marsh villages, the settlements are expanding from the inside out in a radial or } \\
\text { centrally directions. } \\
\text { In palm forest villages settlements are created in separate and parallel blocks along the } \\
\text { palm forest strip and grow with the addition. outside the settlement or between the } \\
\text { existing villages. } \\
\text { In desert, context settlements grow from the outside inward. }\end{array}$ \\
\hline
\end{tabular}




\subsection{The nature of the settlement economy}

The economy of the settlements and the form in which these settlements were assembled is determined by the type of context and its economic resources; In the open marsh villages [22], the settlements are spread around reed fields with exits of the village through these fields to water buffalo grazing and fishing areas, while the dwellings of palm forest villages are distributed in a striped form along with the palm forests and on the edges of the water canals. There is no clear planning pattern in the villages of the desert lands along the marshes, which depends on the availability of the area of grazing areas for camels and sheep.

\subsection{The settlement growth pattern}

This factor is also determined by the nature of the context where the settlement is located in the open marshes, and where the housing is centered in the water, an area of water bodies is left for future expansion and extension. Adding new areas to the original island or creating new islands nearby. In the areas of palm forests, settlements are created in separate and parallel blocks along the palm forest strip and grow with the addition of settlements or dwellings. Outside the settlement or between the existing villages.

\section{CONCEPTS OF SPACE AND HOUSING}

The general concept of space in the marshes is a reflection of the environment, where the context gives more breadth and divergence than the dryland environment [24]. Here the main advantage is that the village in the marshes does not have a boundary for an extension. There is no specific size or specifications that can be considered suitable for the establishment of the village, as the existing natural environment is identical and repeated over miles in all directions around any site. Therefore, the village in the marsh grows and expands from the inside out, while the villages in the drylands grow from the outside (where the village borders) inward. The general principle of the formation and growth of settlement spaces in marsh areas is when a family creates its own residential space It starts by adding another building near the original one such as kitchen, warehouse and animal enclosures, the growth and replacement of residential space depends on the age of the structure and the age of the construction materials, which is influenced by environment impact by vanishing and decomposition. Structures built of reeds have a lifespan of 5-8 years and that of clay can last for 10-15 years, and therefore, the shape of the space is constantly changing. For the housing units in the marshlands, the pattern of spaces orientation has affected the determination of the overall layout of the housing: Outward-oriented spaces is a typical pattern in open marsh areas, space oriented towards an inner courtyard is the typical pattern in drylands around the marshlands, a mixed pattern depends on the integration of the two concepts together in irrigated lands [19].

\section{ENVIRONMENTAL ADAPTATION}

\subsection{Temperatures}

The marsh environment contributes to moderating the temperature. Waterworks as a reservoir to control temperature differences. Although the temperature difference between winter and summer is little, compared to other areas in Iraq, environmental solutions have varied according to the season. In winter reed blinds are used to repel cold winds in most reed buildings with different and varied models of knitting, reeds itself is a good insulation material so it helps when used in construction to increase the thermal insulation, and its efficiency increase when mixed with clay, for the use of solar radiation in winter, nothing interest in this issue was noticed, perhaps because the focus is on the search for shadow areas that can be obtained in the summer. There are no attempts within the homes to increase heating except the use of a fireplace in the middle of the living space. In summer, at high temperatures and the intensity of solar radiation, traditional techniques are harnessed to take advantage of shading the internal spaces, using reed carpets on the openings, in the outside they covered some areas with reeds canopies and high terraces which can be used by residents when needed.

\subsection{Wind}

The northwest wind is the main factor that mitigates the hot and humid weather, so the village is distributed as separated units to allow the maximum amount of wind and maximum ventilation to pass through the summer and winter. In the fall, when the village's main work is fishing, the reed fields around the village are left to grow to serve as windbreaks. However, this process depends on the distribution pattern of the village. Overcrowded villages suffer from poor ventilation and are extremely humid and uncomfortable [24]. The reed fields surrounding villages are an appropriate planning solution, where they reduce the dry east winds in summer. Wind resistance depends on the size and breadth of the village and the degree of dispersion of settlement and its presence in relation to the reed fields.

For the housing unit, some solutions have been noticed such as turning the spaces of the residence in different directions, Because the south-oriented spaces will suffer from the problems of brightness and the reflection of solar radiation on nearby water surfaces, the most of these spaces were directed towards the northwest to receive the largest amount of wind and reduce the walls that are exposed to the sun. In the south, the areas that need solarization are placed, such as some living spaces, warehouses, and elevated terraces, which are used to dry animal feces to be used as fuel.

\subsection{Humidity}

Moisture is high in the atmosphere and soil, and there are no practical solutions followed at the level of settlements, except the presence of reed fields that are high in front of the village and in the face of the wind to help absorb moisture, especially those coming with the wind. On days when the air is dry or low humidity on neighboring lands, the air will be saturated with moisture when passing through the water bodies surrounding the village and become cooler before passing through the village, but this problem is exacerbated when the air humidity rises and there is no airflow, the atmosphere becomes stifling and the need for wind movement become urgent. This problem appears in settlements as a result of evaporation from nearby water bodies, and it occurs for most of the year, in reed buildings, this problem was solved by using a wall opening that allowed air to penetrate into the dwelling 
(Figure 11).

Humidity has another negative role, especially when there is no or less ventilation; it provides a favorable atmosphere for the growth of fungi that erode and damage the reed stems. This leads to corrosion of floors, foundations, and structure and this has made the maximum life of the building between 10-15 years an ideal condition [25].

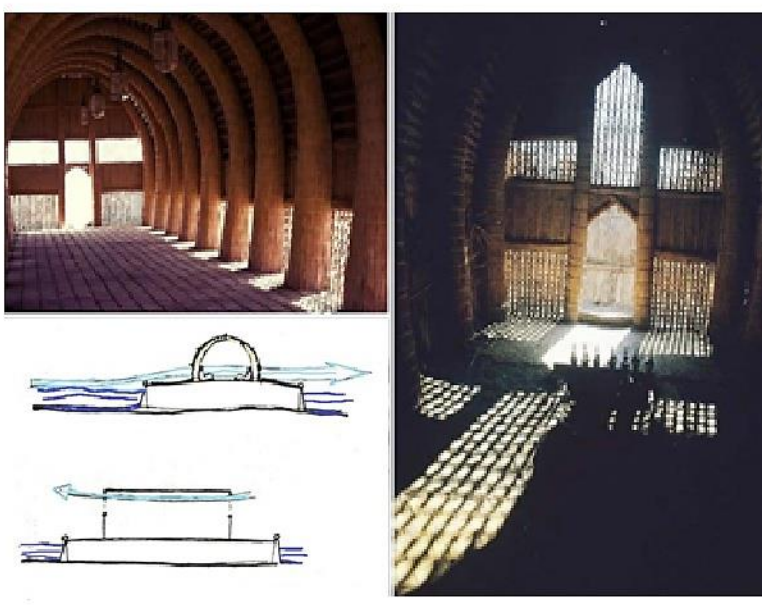

Figure 11. Air penetrating the dwelling $[13,26]$

\subsection{Rain and storms}

The problem of rain, in general, is a low-impact problem if not accompanied by storm winds, there is no need in most cases to drain rainwater, it flows directly to the marshes or nearby water bodies, In the case of storms, which is a rare occurrence, the reed fields surrounding the settlement contribute slightly in reducing the intensity of wind and its impact on the settlement, Gables and arched ceilings contributed to the drainage of rainwater from the house and quickly, Some islands surfaces may be convex, making them efficient in draining water.

\subsection{Floods}

It is a severe problem for all the inhabitants of the marshes, whether in open marshland or located in areas threatened to submerge or rise in water levels, this phenomenon has been dealt with through Constructing artificial islands called Aljabayesh [27], which are above the water level. However, they remain vulnerable to sinking at some exceptional water level rises, and then there is no possible solution other than adding thick reed mats on the floors inside and outside the dwelling to raise the level of the ground, Sand barriers are also constructed on the coasts of these islands of reeds, which reduces water flow into the island. However, these islands suffer from their extinction over time because of the factors of erosion and decay and this requires adding reeds and mud constantly. Another solution is to lift parts of the house on columns of reeds (summer terraces), where they can be used as a shelter in exceptional cases when the water level rises.

\section{CONCLUSIONS}

The formation of life and architecture in the marshes is directly related to the environment and the environment, so it must be benefited from according to the available elements and in the following way:
A- The presence of reed fields around the village and how to make benefit from them in the response to the climate according to the orientation of each of them: North-West direction: leaves the reeds to grow in the autumn times to repel the monsoons in the winter, and work to reduce them, while it is harvested in the spring to facilitate the passage of wind towards the village Towards dwellings, the south-eastern direction: reeds are harvested in the fall, thereby increasing the amount of solar radiation coming towards the village and its repercussions on water surfaces in the winter, then it is left to grow in the spring to repel strong sunlight in the summer, and also relieve the disturbing southeast hot, dusty winds.

B- Regarding the planning of settlements, it is possible to: take advantage of the water stream to withdraw waste from the area and reduce the pollution of the context, as it makes the scheme similar to the shape of the comb teeth, which secures the exposure of most of the housing to the water stream, which plays the role of withdrawing polluted water from the residential environment. Benefiting from reed fields: In addition to the proposals mentioned above, it is also possible to leave an empty area of reed fields in the form of open water north-west of the village or south-east, which can provide an increase in the amount of wind coming towards the village or repel the sun's southern rays in summer only. In the village site there is a possibility of making the settlement mobile, especially regarding the artificial islands, which have mobility and floating, so it can travel s from one end of the water context to the other, according to climatic changes between winter and summer.

C- Understanding the impact of these factors and relations will help to rebuild settlements, especially for those who have long moved away from the marshes and lost relevance to their architectural heritage. The research clarified that the original characteristics would prevent the emergence of extraneous characteristics, methods of construction, and planning on the marsh architecture that may be carried by these returnees with them.

\section{REFERENCES}

[1] Richardson, C.J. (2018). Mesopotamian Marshes of Iraq. In: Finlayson, C.M., Everard, M., Irvine, K., McInnes, R.J., Middleton, B.A., van Dam, A.A., Davidson, N.C. (eds). The Wetland Book. Springer. https://doi.org/10.1007/978-94-007-4001-3_70

[2] Abusch, T. (2001). The development and meaning of the epic of Gilgamesh: An interpretive essay. Journal of the American Oriental Society, 121(4): 614-622. https://doi.org/10.2307/606502

[3] Eger, A.A. (2011). The swamps of home: Marsh formation and settlement in the early medieval near east. Journal of Near Eastern Studies, 70(1): 55-79. https://doi.org/10.1086/659093

[4] Nicolò, M., Abbas, A.H., Giacomo, B., Giampaolo, L., Giulia, S., Marco, V., Federico, Z. (2019). The rise of urbanized landscapes in Mesopotamia: The QADIS integrated survey results and the interpretation of multilayered historical landscapes. Zeitschrift für Assyriologie und Vorderasiatische Archäologie, 109(2): 214-237. https://doi.org/10.1515/za-2019-0016

[5] Knottnerus, O.S. (2005). History of human settlement, cultural change and interference with the marine environment. Helgoland Marine Research, 59: 2-8. 
https://doi.org/10.1007/s10152-004-0201-7

[6] Papayannis, T., Pritchard, D. (2018). Cultural aspects of wetland management: An overview. In: Finlayson, C.M., Everard, M., Irvine, K., McInnes, R.J., Middleton, B.A., van Dam, A.A., Davidson, N.C. (eds). The Wetland Book. Springer. https://doi.org/10.1007/978-90-4819659-3_252

[7] Nadali, D. (2021). Cities in the water: Waterscape and evolution of urban civilization in southern Mesopotamia as seen from Tell Zurghul, Iraq. In: Jawad, L.A. (eds). Southern Iraq's Marshes: Their Environment and Conservation. Springer International Publishing. https://doi.org/10.1007/978-3-030-66238-7_2

[8] Al-Hamdani, A. (2014). Kingdom of reeds: The archaeological heritage of Southern Iraqi Marshes. Iraq Heritage, 9(1-2): 15-20.

[9] Al-Ansari, N., Adamo, N., Sissakian, V.K. (2019). Water shortages and its environmental consequences within Tigris and Euphrates rivers. Journal of Earth Sciences and Geotechnical Engineering, 9(4): 27-56.

[10] Alabbas, A.A.K., Alumery, A.O. (2021). The natural and environmental resources in the marshes and the means of their investments (Chebaish as a Model). Prospects of Sustainability and Planning of Cities (SPSC 2020) Conference, pp. 1-16. https://doi.org/10.1088/17551315/754/1/012019

[11] Al-Zaidy, K.J., Parisi, G. (2018). Re extrapolation for the Iraq marshes which falling within the world heritage list (a literature review). Al-Qadisiyah Journal for $\begin{array}{lll}\text { Agriculture } & \text { Sciences, } & \text { 8(2): }\end{array}$ https://doi.org/10.33794/qjas.2018.162638

[12] Williams, A.E., Williams, P.O. (2019). Values-based architecture as a regenerative approach to the humanenvironment relationship. Int. J. of Design \& Nature and Ecodynamics, 14(1):

63-74. https://doi.org/10.2495/DNE-V14-N1-63-74

[13] MESSY. (2014). The Floating Basket Homes of Iraq: A Paradise Almost Lost to Saddam. https://www.messynessychic.com/2014/11/12/thefloating-basket-homes-of-iraq-a-paradise-almost-lostto-saddam/, accessed on Sep. 10, 2021.

[14] Al-mudaffar, F.N., Goodwin, K.P., Mahdi, B.A., Stevens, M.L. (2016). Effects of Mesopotamian marsh (Iraq) desiccation on the cultural knowledge and livelihood of marsh Arab women. Ecosystem Health and Sustainability, 2(3): e01207. https://doi.org/10.1002/ehs2.1207

[15] Al-Handal, A., Hu, C. (2014). MODIS observations of human-induced changes in the Mesopotamian marshes in Iraq. Wetlands, 35(1): 31-40. https://doi.org/10.1007/s13157-014-0590-6

[16] Almusaed, A., Almusaed, A. (2015). Building materials in eco-energy houses from Iraq and Iran. Case Studies in Construction Materials, 2: 42-54. https://doi.org/10.1016/j.cscm.2015.02.001

[17] Karstens, S., Langer, M., Nyunoya, H., Čaraite, I., Stybel, N., Razinkovas-Baziukas, A., Bochert, R. (2021). Constructed floating wetlands made of natural materials as habitats in eutrophicated coastal lagoons in the Southern Baltic Sea. Journal of Coastal Conservation, 25(4). https://doi.org/10.1007/s11852-021-00826-3

[18] Fodde, E. (2009). Traditional earthen building techniques in Central Asia. International Journal of Architectural Heritage, 3(2): 145-168. https://doi.org/10.1080/15583050802279081

[19] Al-Azzawi, H.A. (1989). Design study of the open marshlands in Southern Iraq. Master thesis. Department of Architectural Engineering, Baghdad University, Baghdad, Iraq.

[20] https://i.pinimg.com/originals/7c/17/32/7c1732d80a53b 67d29f940071b9e0852.jpg, accessed on Sep. 10, 2021.

[21] U.S. Agency for International Development. (2004). IRAQ MARSHLANDS RESTORATION PROGRAM. U.S. Agency for International Development. https://moen.gov.iq/DesktopModules/Expasys/Docume nts/Download.aspx?ID=43, accessed on Sep. 4, 2021.

[22] Stevens, M., Ahmed, H.K. (2011). Eco-cultural restoration of the Mesopotamian marshes, Southern Iraq. In: Egan, D., Hjerpe, E.E., Abrams, J. (eds). Human Dimensions of Ecological Restoration: Integrating Science, Nature, and Culture. Island Press.

[23] Jawad, L.A. (2021). The daily life of the marsh Arab of the southern marshes of Iraq through a camera lens. In: Jawad, L.A. (eds). Southern Iraq's Marshes. Coastal Research Library, 36. Springer, Cham. http://scihub.tw/10.1007/978-3-030-66238-7_39.

[24] Abd, A.M. (2018). The role of tourism in Economic growth-outlook for the role of tourism in Iraqi marshes development. Journal of Economics and Administrative Sciences, 24(108): 413-427.

[25] Entidhar, A.T., Nadhir, A.A., Knutsson, S. (2012). Progress of building materials and foundation engineering in ancient Iraq. Advanced Materials Research, 446-449: 220-241. https://doi.org/10.4028/www.scientific.net/amr.446449.220

[26] https://cdn.zmescience.com/wpcontent/uploads/2014/12/840x591xmudheif2.jpg.pagesp eed.ic_.SyHeqoDjQ10g4_b6y4hY.jpg, accessed on Sep. 4, 2021 .

[27] Kubba, S. (2011). The Iraqi Marshlands and the Marsh Arabs: The Ma'dan, Their Culture and the Environment. Ithaca Press. 